\title{
The air quality perceptions of the residents of Bayview, Mossel Bay
}

\author{
Johann P. Schoeman ${ }^{* 1}$ and De Wet Schutte ${ }^{2}$ \\ ${ }^{128}$ Maroela Street, Mossel Bay, Western Cape, 6500, South Africa, jschoeman@edendm.co.za \\ ${ }^{2}$ Cape Peninsula University of Technology, Post Office Box 652, Cape Town 8000, South Africa
}

\begin{abstract}
Background: In developing countries, it often occurs that little attention is given to air pollution emissions due to a lack of proper town planning, household combustion processes, energy production and the continuous growth in the transport sector (Norman et al., 2007:783). There is an increase in urban air pollution in most of the major cities of developing countries which is amplified by population growth and industrialization (World Resource Institute, 1998, 1999:1). Air pollution studies are not complete, and may fail if the quality of life and the perceptions of the studied community are not taken into consideration. This paper investigates the air quality perceptions of a high income residency surrounded by industrial activities and Mossel Bay was rated as to have potentially poor air quality by the South African Department of Environmental Affairs and Tourism.

Methods: A cross-sectional survey was carried out in Bayview, Mossel Bay. The perceptions of the respondents were collected by a structured questionnaire. Components of perceptions that were tested included general opinion regarding air quality, visual perceptions of air quality, type of pollutants such as smoke and dust, perceptions regarding the source of air pollution, perceptions regarding the municipal health institution controlling air quality in Bayview, etc. These perceptions were investigated by age, gender, socio-economic status etc.

Conclusion: The findings of the study indicated that various factors, such as visual impacts, type of pollutants, role of the municipal health institution governing air quality, influence the air perceptions of the Bayview residents.
\end{abstract}

\section{Keywords}

air pollution, perceptions, air quality, monitoring, visual impacts, exposure, social status, local knowledge

\section{Introduction}

In developing countries it often occur that little attention is given to air pollution emissions due to a lack of proper town planning, household combustion processes, energy production and the continuous growth in the transport sector (Norman et al., 2007). Most of the major cities of developing countries show an increase in urban air pollution which is amplified by population growth and industrialisation (World Resource Institute, 1998, 1999).

One of the major air quality problems in South Africa is poor regional and town planning, often driven by political ideologies where residential areas are developed adjacent or next to industrial areas (Matooane et al., 2004). Mossel Bay was no exception to this rule and Bayview, one of the suburbs of this developing town is surrounded by industrial activities. The Mossel Bay region was also classified by the Department of Environmental Affairs as to have potentially poor air quality. One of the reasons for this classification was the petro-chemical industry situated $10 \mathrm{~km}$ west of the Bayview residency. This industry triggered other industrial activities in the region. Considerable emphasis is placed on the monitoring of air pollutants that pose a risk and important aspects such as personal and community opinions on air quality and the effect on their health are often overlooked (Hunter et al., 2003).
The development of perceptions about environmental pollution is a complex process due to the culmination of a wide spectrum of possible sensory inputs that could converge into perceptions Bickerstaff, 2003). In this respect it is clear that attitudes and concerns that an individual might have concerning the environment can play an important role in what is perceived as an environmental hazard (Stenlund et al., 2009). Therefore, a general definition of risk perception is that it includes a person's attitute, behaviour, beliefs, opinions and concerns for the environmental hazard (Stenlund et al., 2009). Bickerstaff (2003) takes this notion further as he argues that risk perceptions include the wider cultural and social disposition of people towards dangers and the disadvantages thereof. From this approach it is clear that perceptions regarding air pollution are predominantly based on the visual and chemo-sensory indicators, and showed as being useful indicators for possible air pollution when one has to mediate between environmental exposure and health (Stenlund et al., 2009).

Hunter et al., (2003) recorded that public stress related to the potential health effects of air pollution on individuals and their families increased over the last decades. Hunter et al., (2003) furthermore mentioned various studies have been published on air pollution and the prevalence of respiratory diseases, the link between these two variables are still not clear, simply because of the lack of scientifically acceptable control over the 
variables in a real world setting. In this respect it was found that local knowledge could play an important role in shaping the people's perceptions of environmental risks (Scammel et al., 2009). Research on perceptions of environmental risks showed that local context and experience plays an important role in the definition and perceptions of environmental risks (Bickerstaff, 2004). Added to this, it is also known that risk perceptions are also influenced by an individual's perception of the credibility of the environmental health institution that has to take care of his/ her health (Scammel et al., 2009).

Hyslop (2009) argued that the human physiology and psychology is particularly sensitive for visual inputs and that the observable, impacts to a large extent dictate how people perceive the world around them. Although man usually tends not to pay attention to his environment, it still consciously or subconsciously, influences how he sees life (Hyslop, 2009). However, since the 1960 's there been a growing sensitivity for air pollution, mainly as a result of increased publicity, with the result of increased awareness regarding air quality (Hyslop, 2009).

This paper investigates the perceptions regarding the air quality of Bayview, middle to upper income residential suburb of Mossel Bay in South Africa. Being surrounded by industrial activities, Mossel Bay was rated by the South African Department of Environmental Affairs as having potentially poor air quality.

\section{Methods}

Bayview is middle to upper income residential suburb of Mossel Bay and is almost surrounded by industrial activities that include petrochemical storage tanks, a coal burning food industry, light industrial activities and also railway activities operating steam and diesel locomotives. A systematic sample of 114 plots (total 483) was selected from a cadastral map of Bayview. The sample size was calculated by means of Statcalc statistical software using a confidence interval of 5 points and a confidence level of $95 \%$ accuracy. A Politz frame was used to randomly select a respondent among the members of the selected household that qualifies for this study. Respondents that qualified for selection by means of the Politz frame had to be 18 years of age and older, usually sleep in the household and lived in the house since January 2009. The normal ethical conditions like anonymity, informed consent and voluntary participation applied during data collection. The research study and questionnaire was approved by the Cape Peninsula University of Technology Ethical Committee and Applied Sciences Higher degrees Committee.

The target population for this study consisted of all the residents that were 18 years and older and that have resided in Bayview for at least one year prior to the data collection for this research project. A questionnaire was designed to yield information regarding the perceptions of the residents regarding the air quality of the area. The questionnaire was based on literature research making use of the dendrogram-technique which is a conceptual framework highlighting the research questions on the lowest level of the dendrogram. The questionnaire included sections on quality of life and perceptions. The section on perceptions included questions such as length of stay in Bayview, visibility of pollution and industrial activity, evaluating the general air quality of bayview, perception on industrial activity with biggest impact, perception on pollution control at industrial level and authority level, etc. Risk perceptions are also influenced by a person's perception of the worthiness of the health institution that has to protect that person's health (Scammel et al., 2009). In order to test this theory the question of how the respondent perceived the health institution responsible for the health of the Bayview residents, was posed.

Independent variables in this evaluation were the respondent's age, gender, and period of residency, self reported health status, health consciousness, and exposure to polluted air in the workplace. Dependent variables in this study were their general perceptions of the air quality and visibility of air pollutants in Bayview. The results of the questionnaire were coded and analysed with the StatSoft Statistica version 9 software package. Chi square analysis was used to search for statistical significant relationships between independent and dependent variables.

\section{Results and discussion}

Table 1 shows the sample demographics for the 114 respondents.

Table 1: The age distribution of respondents

\begin{tabular}{|l|l|l|}
\hline Age & $\mathbf{n}$ & $\%$ \\
\hline $18-23$ & 5 & 4.4 \\
$24-30$ & 3 & 2.6 \\
$31-45$ & 20 & 17.5 \\
$46-60$ & 41 & 36 \\
$61+$ & 45 & 39.5 \\
\hline Total & $\mathbf{1 1 4}$ & $\mathbf{1 0 0 . 0}$ \\
\hline
\end{tabular}

The age distribution indicated that the age group of $61+$ was the highest age group in Bayview. Only $4.4 \%$ respondents were between 18 and 23 years old. The age profile thus indicated a high age profile.

Table 2: The comparison between male and female of the respondents

\begin{tabular}{|l|l|l|}
\hline Sex & $\mathbf{n}$ & $\%$ \\
\hline Male & 52 & 45.6 \\
\hline Female & 62 & 54.3 \\
\hline Total & $\mathbf{1 1 4}$ & $\mathbf{9 9 . 9}$ \\
\hline
\end{tabular}

Females were the predominant sex with a sex distribution of $54.3 \%$ female and $45.6 \%$ male respondents.

Table 3: The length of residency in Bayview

\begin{tabular}{|l|l|l|}
\hline Length of residency in Bayview & $\mathbf{n}$ & $\%$ \\
\hline 0 - 5 years & 32 & 28.1 \\
6 - 10 years & 19 & 16.7 \\
11 - 20 years & 44 & 38.6 \\
21 years and longer & 19 & 16.6 \\
\hline Total & $\mathbf{1 1 4}$ & $\mathbf{1 0 0 . 0 0}$ \\
\hline
\end{tabular}


Thirty-eight point six percent of the population resided in Bayview between $11-20$ years and $16.6 \%$ for longer than 21 years. Based on this information it was derived that the population would have known the residency well and that their local knowledge would have been set.

\section{Monitoring results}

The study also took the air quality status of Bayview into account by studying the air quality data of the Department of Environmental Affairs and Development Planning ambient air quality station located in Bayview. The results indicated no exceedences of the South African National Ambient Air Quality Standards for the criteria pollutants. The annual average concentrations of the measured criteria pollutants can be observed in figure 1.

Annual Average $\mathrm{NO}_{2}, \mathrm{PM}_{10}, \mathrm{O}_{3}, \mathrm{C}_{6} \mathrm{H}_{6}$ and $\mathrm{SO}_{2}$ Concentrations Bayview - October 2008- September 2009

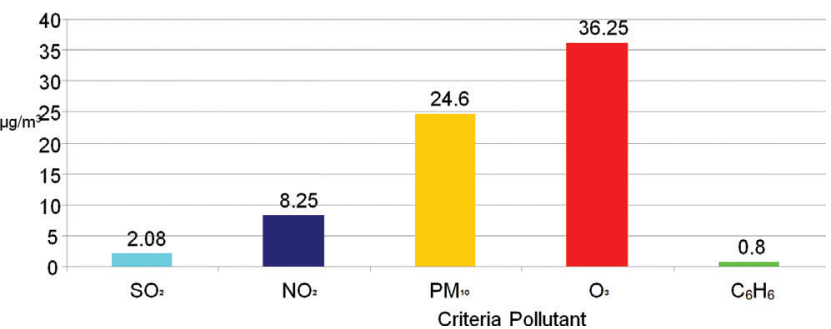

Figure 1: The annual average concentrations of $\mathrm{NO}_{2}, \mathrm{PM}_{10}, \mathrm{O}_{3}, \mathrm{C}_{6} \mathrm{H}_{6}$ and $\mathrm{SO}_{2}$ for the Bayview residency from 1st October 2008 till 30 September 2009

The data of the DEADP monitoring station were captured and compared to the $90 \%$ completeness against the USEPA and SANS1929 standards. See table 4.

Table 4: The annual average of completeness of the captured data for the period 1 October 2009 to 30 September 2009 (South Africa. DEADP, 2009:10)

\begin{tabular}{|l|l|l|l|l|}
\hline Pollutant & SO$_{2}$ & $\mathbf{N O}_{2}$ & $\mathbf{O}_{3}$ & $\mathbf{P M}_{\text {。 }}$ \\
\hline \% collected & $96.8 \%$ & $98.9 \%$ & $92.6 \%$ & $97.6 \%$ \\
\hline
\end{tabular}

\section{Perceptions}

Almost two thirds $63.1 \%$ ( $n=72$ ) of the respondents indicated that they perceived that the air quality was good, with a further $13.2 \%$ $(n=15)$ who rated the air quality as excellent, whilst $19.3 \%(n=22)$ thought it was average (Table 5). The minority of respondents rated the air quality as poor to very poor $(4.3 \%, n=5)$.

Table 5: The perceptions of the Bayview respondents on the status of air quality

\begin{tabular}{|l|l|l|}
\hline Opinion of the Bayview air quality & $\mathbf{n}$ & $\%$ \\
\hline Excellent & 15 & 13.2 \\
Good & 72 & 63.1 \\
Average & 22 & 19.3 \\
Poor & 4 & 3.5 \\
Very poor & 1 & 0.8 \\
\hline Total & $\mathbf{1 1 4}$ & $\mathbf{9 9 . 9}$ \\
\hline
\end{tabular}

Results of the logistic regression showed that the following factors may influence perceptions of air quality among the residents of Bayview, Mossel Bay. Although various influences such as age, gender, length of stay, etc were tested, only the factors with statistical significance $(P<0.05)$ are mentioned in this paper.

\section{Visual impacts}

Because visual impact plays an important role in the formation of perceptions regarding air quality, respondents were asked what they consider to be the main contributors to air pollution in Bayview. The results show that the perceived main contributor to pollution in the area is the Food factory $(34.2 \%$, $n=39)$, followed by $(19.3 \%, n=22)$ that perceive it is one of the local transport companies, followed by Petrochemical storage facility and the railway loco, both on $(15.8 \%, n=18)$. (See Table 6)

Table 6: Perceptions of Bayview respondents regarding the surrounding industries with the biggest air quality impact

\begin{tabular}{|l|l|l|}
\hline $\begin{array}{l}\text { Industries with the major impact on Bayview air } \\
\text { quality }\end{array}$ & $\mathbf{n}$ & $\%$ \\
\hline Not answered & 3 & 2.6 \\
\hline Petrochemical Storage facility & 18 & 15.8 \\
\hline Local transport company & 22 & 19.3 \\
\hline Railway loco & 18 & 15.8 \\
\hline Tank farms & 8 & 7.0 \\
\hline Oil tankers & 4 & 3.5 \\
\hline Food Factory & 39 & 34.2 \\
\hline Seal island & 2 & 1.8 \\
\hline Total & $\mathbf{1 1 4}$ & $\mathbf{1 0 0}$ \\
\hline
\end{tabular}

\section{Exposure to air pollution}

The study found a statistically significant correlation $(p=0.035)$ between the perception of the air quality of Bayview and the perception of the influence of the industries on the respondents' health (Table 7 ). It was found was that the respondents $(80 \%$, $\mathrm{n}=12$ ) that perceived the air quality as excellent also indicated that the surrounding industries do not have a negative impact on their health. The same tendency was found with the respondents that perceived the air quality as good, when $61.1 \%(n=44)$ indicated that the surrounding industries do not have a negative influence on their health. This tendency was further confirmed when the majority $(54.5 \%, n=12)$ among the 22 respondents $(19.3 \%)$ that rated the air quality as average, indicated that they perceived that the industries do have a negative impact on their health.

Table 7: The correlation between the perceptions of air quality and the perceptions of the impact of the industries on the health of the respondents

\begin{tabular}{|c|c|c|c|c|c|c|c|c|}
\hline \multirow{2}{*}{$\begin{array}{l}\begin{array}{l}\text { Perceptions } \\
\text { of air quality }\end{array} \\
\text { Excellent } \\
\text { Good } \\
\text { Average } \\
\text { Poor } \\
\text { Very poor }\end{array}$} & \multicolumn{2}{|c|}{$\begin{array}{l}\text { Industries } \\
\text { do influence } \\
\text { my health }\end{array}$} & \multicolumn{2}{|c|}{$\begin{array}{l}\text { Industries } \\
\text { does not } \\
\text { influence } \\
\text { my health }\end{array}$} & \multicolumn{2}{|c|}{$\begin{array}{l}\text { Unsure, if } \\
\text { industries } \\
\text { influence } \\
\text { my health }\end{array}$} & \multicolumn{2}{|c|}{ Total } \\
\hline & $\begin{array}{l}1 \\
15 \\
12 \\
3 \\
1\end{array}$ & $\begin{array}{l}\% \\
6.7 \\
20.8 \\
54.5 \\
75.0 \\
100.0\end{array}$ & $\begin{array}{l}\mathrm{n} \\
12 \\
44 \\
6 \\
0 \\
0\end{array}$ & $\begin{array}{l}\% \\
80.0 \\
61.1 \\
27.3 \\
0.0 \\
0.0\end{array}$ & $\begin{array}{l}n \\
2 \\
13 \\
4 \\
1 \\
0\end{array}$ & $\begin{array}{l}\% \\
13.3 \\
18.1 \\
18.2 \\
25.0 \\
0.0\end{array}$ & $\begin{array}{l}n \\
15 \\
72 \\
22 \\
4 \\
1\end{array}$ & $\begin{array}{c}\% \\
100.0 \\
100.0 \\
100.0 \\
100.0 \\
100.0\end{array}$ \\
\hline Total & 32 & 28.1 & 62 & 54.4 & 20 & 17.5 & 114 & 100.0 \\
\hline
\end{tabular}

Pearson Chi-square: $22.8375, \mathrm{df}=8, \mathrm{p}=.003582$ 


\section{Social status}

Perceptions are also influenced by the environment, availability of information and socio-economic characteristics (MacKerron et al., 2009). Previous studies indicated that the more wealthy communities have the perception that air quality imposes a bigger threat to the less fortunate communities (Bickerstaff, 2004). The social status of the Bayview suburb was high. It was derived from their income level, work level and educational level. Thirty seven point eight percent, $(n=43)$ respondents were professional, $39.4 \%,(n=45)$ had an annual income of R180 001 and higher and $43.8 \%,(n=50)$ had a degree or diploma. This research found a correlation between qualification and perceptions.

Table 8: The correlation between perceptions of air quality and the industrial emission control

\begin{tabular}{|c|c|c|c|c|c|c|c|c|}
\hline \multirow{2}{*}{$\begin{array}{l}\text { Qualifica- } \\
\text { tion } \\
\\
<\text { Grade } 12 \\
\text { Grade } 12 \\
>\text { Grade } 12\end{array}$} & \multicolumn{2}{|c|}{$\begin{array}{l}\text { Yes, indus- } \\
\text { tries emis- } \\
\text { sion control }\end{array}$} & \multicolumn{2}{|c|}{$\begin{array}{l}\text { No, indus- } \\
\text { tries emis- } \\
\text { sion control }\end{array}$} & \multicolumn{2}{|c|}{$\begin{array}{l}\text { Unsure, } \\
\text { industries emis- } \\
\text { sion control }\end{array}$} & \multicolumn{2}{|c|}{ Total } \\
\hline & $\begin{array}{l}n \\
10 \\
13 \\
8\end{array}$ & $\begin{array}{l}\% \\
55.6 \\
28.3 \\
16.0\end{array}$ & $\begin{array}{l}\mathrm{n} \\
2 \\
13 \\
17\end{array}$ & $\begin{array}{l}\% \\
11.1 \\
28.3 \\
34.0\end{array}$ & $\begin{array}{l}\% \\
11.1 \\
28.3 \\
34.0\end{array}$ & $\begin{array}{l}\% \\
33.3 \\
43.5 \\
50.0\end{array}$ & $\begin{array}{l}\mathrm{n} \\
18 \\
46 \\
50\end{array}$ & $\begin{array}{l}\% \\
100.0 \\
100.1 \\
100.0\end{array}$ \\
\hline Total & 31 & 27.2 & 32 & 28.0 & 51 & 44.8 & 114 & 100.0 \\
\hline
\end{tabular}

Pearson Chi-square: $10.9681, \mathrm{df}=4, \mathrm{p}=.026931$

Eighteen of the respondents $(15.7 \%) n=18$ had qualifications lower than grade 12 . Of those, $11.1 \% \mathrm{n}=2$ indicated that the industries don't do enough to control emissions, $33.3 \% n=6$ was unsure and $55.6 \% \mathrm{n}=10$ indicated adequate emission control. Forty six $(40.4 \%)$ respondents had grade 12 . Of those, $28.3 \%,(n=13)$ indicated that industries don't do adequate emission control and almost half $(43.5 \%, n=20)$ indicated that they don't know. Forty three point eight percent $n=50$ had a qualification higher than grade 12 (diploma or degree) of which $34 \%,(n=17)$ indicated that industries do not control emissions adequately and 50\%, $(n=25)$ indicated that they don't know. The perceptions of emission control fluctuated over educational qualification. The higher the qualification thus the higher the perception that industries do not implement adequate emission control. These groups were also unsure if the industries are doing emission control.

\section{Risk perceptions and the perceptions of} the air quality authority regulating air quality in Bayview

It was clear that the majority of the respondents that classified the air quality as excellent and good ( $\mathrm{n}=15$ and 72 respectively) did not know how to judge the health authority $(46.7 \%$ and $36.1 \%$ respectively) (Table 9$)$. Of these two groups, the second highest percentage $(26.7 \%, \mathrm{n}=4$ and $34.7 \%, \mathrm{n}=25)$ respectively also judged the health institution as good.

Table 9: The correlation between the perceptions of the Bayview respondents and the perception of the air quality authority

\begin{tabular}{|c|c|c|c|c|c|c|c|c|c|c|c|c|}
\hline \multirow{2}{*}{$\begin{array}{l}\begin{array}{l}\text { Perception } \\
\text { air quality }\end{array} \\
\text { Excellent } \\
\text { Good } \\
\text { Average } \\
\text { Poor } \\
\text { Very poor }\end{array}$} & \multicolumn{2}{|c|}{$\begin{array}{l}\text { Health } \\
\text { institutions } \\
\text { excellent }\end{array}$} & \multicolumn{2}{|c|}{$\begin{array}{l}\text { Health } \\
\text { institutions } \\
\text { good }\end{array}$} & \multicolumn{2}{|c|}{$\begin{array}{l}\text { Health } \\
\text { institutions } \\
\text { average }\end{array}$} & \multicolumn{2}{|c|}{$\begin{array}{l}\text { Health } \\
\text { institutions } \\
\text { poor }\end{array}$} & \multicolumn{2}{|c|}{$\begin{array}{l}\text { Health } \\
\text { institutions } \\
\text { don't know }\end{array}$} & \multicolumn{2}{|l|}{ Total } \\
\hline & $\begin{array}{l}n \\
3 \\
1 \\
0 \\
0 \\
0\end{array}$ & $\begin{array}{c}\% \\
20.0 \\
1.4 \\
0.0 \\
0.0 \\
0.0\end{array}$ & $\begin{array}{l}\mathrm{n} \\
4 \\
25 \\
5 \\
1\end{array}$ & $\begin{array}{l}\% \\
26.7 \\
34.7 \\
22.7 \\
25.0 \\
0.0\end{array}$ & $\begin{array}{l}n \\
1 \\
18 \\
6 \\
0 \\
0\end{array}$ & $\begin{array}{l}\quad \% \\
6.7 \\
25.0 \\
27.3 \\
0.0 \\
0.0\end{array}$ & $\begin{array}{l}\mathrm{n} \\
0 \\
2 \\
4 \\
2 \\
1\end{array}$ & $\begin{array}{l}\% \\
0.0 \\
2.8 \\
18.2 \\
50.0 \\
100.0\end{array}$ & $\begin{array}{l}\mathrm{n} \\
7 \\
26 \\
7 \\
1 \\
0\end{array}$ & $\begin{array}{c}\% \\
46.7 \\
36.1 \\
31.8 \\
25.0 \\
0.0\end{array}$ & $\begin{array}{l}n \\
15 \\
72 \\
22 \\
4 \\
1\end{array}$ & $\begin{array}{l}\% \\
100.1 \\
100.0 \\
100.0 \\
100.0 \\
100.0\end{array}$ \\
\hline OTAL & 4 & 3.5 & 35 & 30.7 & 25 & 22.0 & 9 & 7.9 & 41 & 36.0 & 114 & 100.1 \\
\hline
\end{tabular}

\section{The influence of visibility on risk perceptions}

On the question if any of the industries were visible from the respondents dwelling, 59.6\%, $(n=68)$ answered yes and $40.4 \%$, $(n=46)$ answered no. The majority respondents could see an industry from their home (Table 10).

Table 10: The visibility of the industries from the respondent's dwellings

\begin{tabular}{|l|c|l|}
\hline Visibility of the industries & $\mathbf{n}$ & $\%$ \\
\hline Yes & 68 & 59.6 \\
\hline No & 46 & 40.4 \\
\hline Total & $\mathbf{1 1 4}$ & $\mathbf{1 0 0 . 0 0}$ \\
\hline
\end{tabular}

There were $53.5 \%,(n=61)$ respondents that could see smoke from their dwellings (Table 11). More than two thirds $70.1 \%, n=80$ of respondents experienced or saw dust from their dwellings.

Thirteen point two percent respondents $(n=15)$ that perceived the air quality as excellent, the minority or $46.7 \%, \quad(n=7)$ experienced or saw smoke from their houses. Almost two thirds or $(63.2 \%, \mathrm{n}=72)$ respondents that perceived the air quality to be good, the minority or $45.8 \%, n=33$ could see smoke from their dwellings. Four respondents perceived the air quality as poor and all of them, $n=4$ could see smoke from their dwellings.

Table 11: The correlation between perceptions and the experiencing or visibility of smoke.

\begin{tabular}{|l|l|l|l|l|l|r|}
\hline Perception of air quality & \multicolumn{3}{|l|}{$\begin{array}{l}\text { See } \\
\text { smoke }\end{array}$} & \multicolumn{2}{l|l|}{$\begin{array}{l}\text { Don't see } \\
\text { smoke }\end{array}$} & \multicolumn{2}{l|}{ Total } \\
\hline & $\mathrm{n}$ & $\%$ & $\mathrm{n}$ & $\%$ & $\mathrm{n}$ & $\%$ \\
Excellent & 7 & 46.7 & 8 & 53.3 & 15 & 100.0 \\
Good & 33 & 45.8 & 39 & 54.2 & 72 & 100.0 \\
Average & 17 & 77.3 & 5 & 22.7 & 22 & 100.0 \\
Poor & 4 & 100.0 & 0 & 0.0 & 4 & 100.0 \\
Very poor & 0 & 0.0 & 1 & 100.0 & 1 & 100.0 \\
\hline Total & $\mathbf{6 1}$ & $\mathbf{5 3 . 5}$ & $\mathbf{5 3}$ & $\mathbf{4 6 . 5}$ & $\mathbf{1 1 4}$ & $\mathbf{1 0 0 . 0}$ \\
\hline
\end{tabular}

Pearson Chi-square: $11.6079, \mathrm{df}=4, \mathrm{p}=.020523$

\section{Conclusion}

This study found the higher the social status in terms of qualification, thus the lower the perception regarding the risk. Smoke posed a significant impact on the perceptions of the respondents. The importance of visibility was also emphasized as the industry that was most visible was also perceived as the industry with the biggest threat or impact. There is a correlation between general air quality perceptions and industrial air quality impact. There is a correlation between air quality perceptions and the perceptions of the air quality authority regulating air quality of that specific population.

\section{References}

Bickerstaff, K. 2004. Risk Perception research: socio-cultural perspectives on the public experience of air pollution. 2004. Environment International volume 30 (2004). Science direct. 
www.elseriver.com/locate/envint Pages 827-840. [11 August 2009].

Carter, S., Williams. M., Paterson, J., Iusitini, L. 2008. Do perceptions of neighbourhood problems contribute to maternal health? Findings from the Pacific Islands Families study. (PIF) Study, AUT University, Auckland, New Zealand. Health \& Place. 2008. www.elserivier.com/locate/healthplace Pages. 622-630. [15 May 2009].

Encyclopedia Britannica. 2009. Encyclopedia Britannica Online. 2009. http://www.search.eb.com/eb/article-9110465 Pages. 1-3. [22 May 2009].

Hunter, P., Davies, M., Hill, K., Whittaker, M., Sufi, F. 2003. The prevalence of self-reported symptoms of respiratory disease and community belief about the severity of pollution from various sources. September 2003. The International Journal of Environmental Health Research 13(3). Taylor and Francis Health Sciences. London UK. Pages 227-338.

Hyslop, N. 2009. Impaired visibility: the air pollution people see. Atmospheric Environment 43 (2009). Science Direct. www. elsvier.com/locate/atmosenv Pages 182-185. [22 May 2009].

Mackerron, G., Mourato, S. 2009. Life satisfaction and air quality in London. 2009. Ecological Economics Vol. 68 (2009) Science Direct. www.elserivier.com/locate/ecolecon Pages 1441-1450. [20 July 2009].

Matooane M., John, J., Oosthuizen, R en Binedell, M. 2004. Vulnerability of South African Communities to Air Pollution. Proceedings of the 2004 Conference of the South African Institute of Environmental Health, Durban, 22-27 February 2004.

Norman, R., Eugene Cairncross, Jongikhaya Witi, Debbie Bradshaw. 2007. Estimating the burden of disease attributable to urban outdoor air pollution in South Africa in 2000. South African Medical Journal, 97(7) August 2007. Pages 782-790.

Scammel, M., Senier, L., Darrah-Okike, J., Brown, P. 2009. Tangible evidence, trust and power: Public perceptions of community environmental health studies. Social Science \& Medicine, 68(2009). Science Direct. www.elsevier.com/locate/ socscimed Pages 143-146. [22 May 2009].

Stenlund, T., Lide, E., Andersson, K., Garvill, J., Nordin, S. 2009. Annoyance and health symptoms and their influencing factors: $A$ population-based air pollution intervention study. Public Health. 2009. Science Direct. www.elsevierhealth.com/journals/pubh Pages 339-345. [15 May 2009].

World Resource Institute. Health and Environment,1998,1999. Health Effects of Air Pollution. http://www.wri.org/wr-98-99/ airpoll.htm [11 May 2009] 